\title{
Hydrological responses to climate changes in a headwater watershed
}

\author{
Respostas hidrológicas de uma bacia hidrográfica de cabeceira \\ às mudanças climáticas
}

\author{
Lívia Alves Alvarenga1*, Carlos Rogério de Mello', Alberto Colomboํ, Luz Adriana Cuartas², Sin Chan Chou \\ ${ }^{1}$ Universidade Federal de Lavras/UFLA, Departamento de Engenharia/DEG, Lavras, MG, Brasil \\ ${ }^{2}$ Centro Nacional de Monitoramento e Alertas de Desastres Naturais/CEMADEN, São José dos Campos, SP, Brasil \\ ${ }^{3}$ Centro de Previsão de Tempo e Estudos Climáticos, Cachoeira Paulista, SP, Brasil \\ ${ }^{*}$ Corresponding author: livia.aalvarenga@deg.ufla.br \\ Received in July 7, 2016 and approved in September 28, 2016
}

\begin{abstract}
Climate change impacts need to be considered in water resource planning. This work aims to study of the impacts climate change on Lavrinha headwater watershed, located in the Mantiqueira Range, southeastern Brazil. The impacts from climate change (RCP 8.5 scenario) in the Lavrinha watershed runoff were analyzed based on the "Distributed Hydrology Soil Vegetation Model" (DHSVM), forced with the climate simulated for this future climate change scenario. These simulations, in turn, were generated by the Eta regional climate model coupled to Global Climate Model (GCM) HadGEM2-ES for the 2011-2040, 2041-2070 and 2071-2099 periods. The results of this study showed that the runoff is very sensitive to rising temperatures and reduced precipitation, both projected for the RCP 8.5 scenario. The hydrological simulation projected a reduction in the monthly streamflow between 20 and $77 \%$ over the twenty-first century (2011-2099), corresponding to drastic reductions in the runoff behavior and consequently in the water production capacity of the region.
\end{abstract}

Index terms: Downscaling; Eta model; DHSVM; hydrological impacts.

\section{RESUMO}

O impacto das mudanças climáticas precisa ser considerado no planejamento dos recursos hídricos. Este trabalho tem por objetivo o estudo dos impactos das mudanças climáticas na bacia de cabeceira Lavrinha, localizada na Serra da Mantiqueira, Sudeste do Brasil. Os impactos oriundos das mudanças climáticas (cenário RCP 8.5) no escoamento da bacia hidrográfica Lavrinha foram analisados com base no modelo "Distributed Hydrology Soil Vegetation Model" (DHSVM), forçado com as condições climáticas simuladas para este cenário futuro de mudanças climáticas. Estas simulações, por sua vez, foram geradas pelo modelo climático regional Eta acoplado ao Modelo Climático Global (MCG) HadGEM2-ES, nos períodos de 2011-2040, 2041-2070 e 2071-2099. Os resultados deste estudo mostraram que a vazão é bastante sensível ao aumento da temperatura e diminuição da precipitação, ambos projetados para o cenário RCP 8.5. A simulação hidrológica projetou uma redução na vazão mensal entre 20 e 77\% ao longo do século XXI (2011 a 2099), correspondendo a reduções drásticas no escoamento e, consequentemente, na capacidade de produção de água da região.

Termos para indexação: Downscaling; modelo Eta; DHSVM; impactos hidrológicos.

\section{INTRODUCTION}

Low water availability can cause catastrophic economic, social and environmental problems. Taking into account that the water cycle is affected by possible climate changes and by the vegetation dynamics, the region of the Mantiqueira Range, located in southeastern of Brazil, should be highlighted as an important headwater region in terms of water dynamics (Viola et al., 2015). In addition, the Atlantic forest in these areas is an important biome threatened with extinction. In this context, it is also important to highlight water shortages that occurred in southeastern of Brazil in hydrological years 2013/2014 and 2014/2015 which caused water supply problems for the population (Coelho et al., 2015).

Climate projections of the fifth report of the Intergovernmental Panel on Climate Change (IPCC) (AR5) is based on Representative Concentration Pathways (RCPs) and these scenarios were used for new simulations with climate models made by the project Coupled Model Intercomparison Project Phase 5 (CMIP5). In general, global AR5 models, when compared to models of the fourth IPCC report (AR4), showed improvements in the rainfall simulation, especially for tropical latitudes (Flato et al., 2013). 
In all RCPs, $\mathrm{CO}_{2}$ concentrations in the atmosphere will be higher in 2100 compared with the present period, before 2005. In the AR5, the emission scenarios refer to radiative forcing levels at the end of the XXI century. The RCPs are identified by the total radiative forcing in 2100 , that is, $2.6 \mathrm{Wm}^{-2}$ for RCP 2.6 scenario (mitigation scenario), $4.5 \mathrm{Wm}^{-2}$ and $6.0 \mathrm{Wm}^{-2}$ for the RCP 4.5 and for RCP 6.0 scenarios (stabilization scenarios) and 8.5 $\mathrm{Wm}^{-2}$ for the RCP 8.5 scenario (high greenhouse gas concentrations) (Van Vuuren et al., 2011).

Climate change involves complex interactions and possibilities of various impacts on water and energy balance, even in small watersheds. Thus, the use of hydrological models has been a very effective tool to support decisions about the future of water resources (Mello et al., 2016). The Distributed Hydrology Soil Vegetation Model (DHSVM) is a physical-distributed model tested and validated in mountainous areas in the state of Montana, USA, notably in the Middle Fork Flathead watershed (Wigmosta; Vail; Lettenmaier, 1994). In an overview, the effects of climate changes on water resources have been studied using DHSVM with different downscaling of climate change data (DickersonLange; Mitchell, 2014; Leung; Wigmosta, 1999; Safeeq; Fares, 2012). Thus, the DHSVM was applied to forecast streamflows in the Igarapé Asu watersheds (watersheds of 0.95, 6.58 and $12.43 \mathrm{~km}^{2}$ ) in Amazonia central (Cuartas et al., 2012) and Bocaina river (drainage area of 251.36 $\mathrm{km}^{2}$ ), in São Paulo (Kruk et al., 2009). However, in Brazil, this is the first work applied to climate changes, variability and projections in the annual and monthly streamflow of a headwater watershed, using this model, which is suitable for watersheds in mountainous regions.

Thus, the objective of this study is to evaluate the hydrologic impacts on the streamflow of Lavrinha watershed using the DHSVM simulations associated with future climate-RCP 8.5 scenario (with radiative forcing of $8.5 \mathrm{~W} \mathrm{~m}^{-2}$ ) designed by the Eta regional climate model, which in turn is based on the downscaling of the HadGEM2-ES model projections (Chou et al., 2014a, b).

\section{MATERIAL AND METHODS}

\section{Study area}

The Lavrinha Watershed (LW) has a $6.76 \mathrm{~km}^{2}$ drainage area and is located in the Mantiqueira Range, southeastern Minas Gerais, in the watershed of the Upper Grande River, which is an important river for the generation of electricity in the country. It is also important to emphasize that the hydrological conditions of the watersheds in this region are fundamental information to analyze the possible climate changes projected by hydrological models. The Digital Elevation Model (DEM) of LW, with a resolution of 30 meters, is shown in Figure 1.

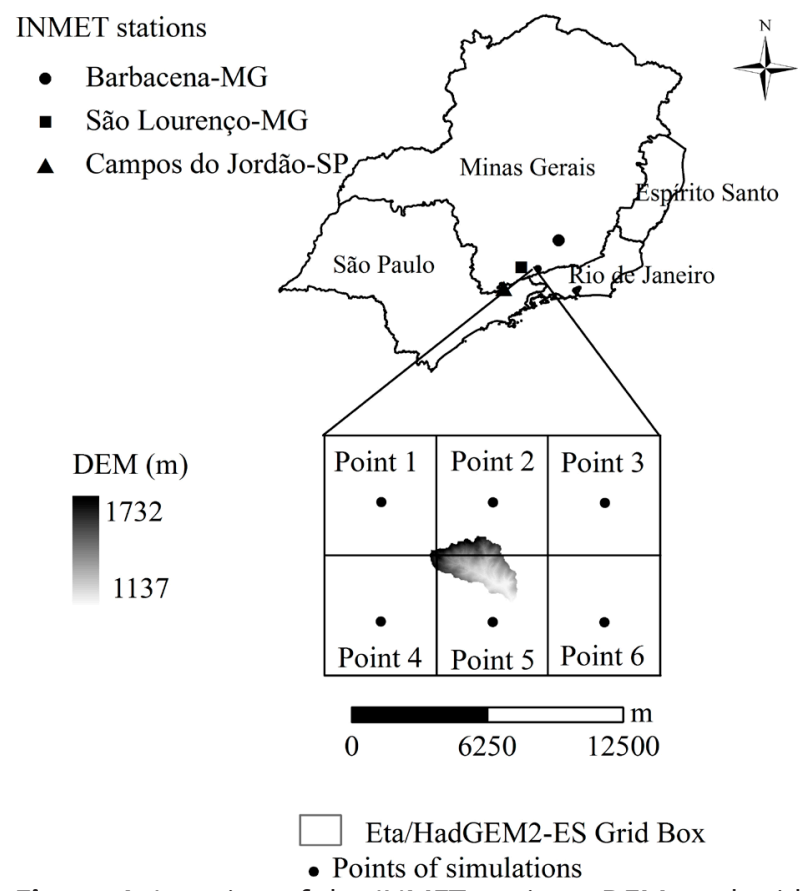
Figure 1: Location of the INMET stations, DEM, and grid box and respective points of Eta/HadGEM2-ES simulations in the LW region, southeast of Brazil (Minas Gerais, Espírito Santo, Rio de Janeiro and São Paulo states).

With average precipitation close to $2045 \mathrm{~mm}$ per year observed between 2006 and 2010, the LW has the rainy season between October and March and the dry season between April and September. The climate in this watershed, according to Koppen classification is the Cwb type (mesothermal) (Mello et al., 2012). The predominant soil class is Cambisol and most of the land is covered by Atlantic forest (Menezes et al., 2014; Pinto et al., 2015).

\section{Climate projections for the study}

Initially, the Eta model at $20-\mathrm{km}$ horizontal resolution was nested to the HadGEM2-ES. These runs are described in Chou et al. (2014 a, b). These authors used a modified version of the Eta regional model (CPTEC/ INPE) obtained from Mesinger et al. (2012). Climatic data available for this study were obtained from the Eta regional model nestled in the General Circulation Model (GCM) 
HadGEM2-ES (Hadley Centre Global Environmental Model) to simulate the present climate (1961-1990 period) and the climate future-RCP 8.5 scenario over the twentyfirst century (2011-2099 period) for all South America and Central America. The 5-km Eta model simulations are produced from a second nesting of the Eta model into the HadGEM2-ES.

The resulting simulations of the Eta model nestled in simulations of the HadGEM2-ES model will, hereafter, be called Eta/HadGEM2-ES. For Eta/HadGEM2-ES simulations analysis performance from 1961 to 1990, they were compared with observed values (climatological normal of the Instituto Nacional de Meteorologia-INMET (Ramos; Santos; Fortes, 2009)) of precipitation and temperature (quarterly average). The nearest stations and with similar altitudes to the studied region are: Barbacena-B (Code: 83689), São Lourenço-SL (Code: 83736) and Campos do Jordão-CJ (Code: 83714) (Figure 1). After verification of the simulated present climate, we obtained the future projection of the simulated streamflow for the 2011-2040, 2041-2070 and 2071-2099 periods.

As the observed data are from regions close to the region of this study, the correction of simulated temperature and precipitation data (correction bias) was not feasible, however, in the work of Chou et al. (2014 a) the simulations of the Eta/HadGEM2-ES were compared to observed data from regions near the present study and the simulations reproduced the climatic characteristics of this region well.

\section{Distributed Hidrology Soil Vegetation Model (DHSVM)}

The DHSVM is a physically based model that provides an integrated dynamic representation of basin processes in the spatial scale described by the Digital Elevation Model (DEM). The model solves the water and energy balance for each grid cell, at each time step.

The DHSVM uses a two-layer canopy model (overstory and understory) for calculating evapotranspiration using the Penman-Monteith equation. The soil surface can receive water from total precipitation, throughfall or surface flow from adjacent cells. The maximum infiltration rate determines the maximum amount of water that can infiltrate at every time step. The water movement in the unsaturated soil is simulated using a model of several layers and each vegetation layer can extract water from one or more soil layers. The percolation is calculated by Darcy's law, using the Brooks-Corey equation to estimate the hydraulic conductivity. The surface flow is generated through saturation and excess infiltration mechanisms. Wigmosta, Vail and Lettenmaier, (1994) presented the DHSVM equations in detail.

\section{Input data for DHSVM}

Data from Eta/HadGEM2-ES simulations were available at intervals of three hours. Thus, the Distributed Hydrology Soil Vegetation Model (DHSVM) was fed in the same interval with atmospheric variables in a spatial grid of $5 \mathrm{~km}$. The climatic data of the central points of the cells to feed the hydrologic model were extracted. DHSVM requires the following meteorological inputs: precipitation $(\mathrm{m})$, temperature $\left(\mathrm{C}^{\circ}\right)$, wind speed $\left(\mathrm{m} \mathrm{s}^{-1}\right)$, relative humidity $(\%)$, shortwave and longwave solar radiation $\left(\mathrm{W} \mathrm{m}^{-2}\right)$.

In this study, the grid cell size in DHSVM is 30 $\mathrm{m} \times 30 \mathrm{~m}$. The vegetation types are Atlantic Forest (63\% of the area) and pasture (37\% of the area) in the LW. Vegetation parameters were not changed in the calibration. There are three types of soils and based on the sensitivity analysis of DHSVM, lateral and vertical soil hydraulic conductivity and exponential decrease rate of lateral soil hydraulic conductivity were used to calibrate the model. Final DHSVM sensitive soil parameters at the end of the calibration were summarized in Table 1. All soil and vegetation parameters were based on literature (e.g. Ávila et al., 2014; Cuartas et al., 2012; Junqueira Junior et al., 2008; Wigmosta; Vail; Lettenmaier, 1994) and details can be found in Alvarenga et al. (2016).

\section{Hydrologic simulations with DHSVM}

In the calibration and validation of DHSVM we used the climate data of a climatological station, located at average LW altitude. An hourly time step was used and the period of January 1, 2005 to September 30, 2006 was selected as the stabilization period (warm up) of the model. For calibration, we selected the period from October 1, 2006 to September 30, 2008. Finally for validation we selected the period from October 1, 2008 to September 30, 2010.

The streamflow in the LW was monitored by means of an automatic water level gauge that recorded the water depth in the control section of the basin. Thus, by means of the stage-discharge rating curve obtained in field campaigns, it was possible to generate the observed streamflow data. The model was calibrated and validated manually searching for a fit between the simulated and observed streamflow (daily and monthly averages) in LW. Thus, the performance of the model was verified based on assessments of the coefficient of determination $\left(\mathrm{R}^{2}\right)$ and Nash-Sutcliffe efficiency (E). 
Table 1: Final soil parameters values for DHSVM.

\begin{tabular}{cccc}
\hline \multirow{2}{*}{ Parameter } & \multicolumn{3}{c}{ Soil type } \\
\cline { 2 - 4 } & $\begin{array}{c}\text { Haplic Cambisol } \\
(92 \% \text { of the area })\end{array}$ & $\begin{array}{c}\text { Haplic Gleisol } \\
(1 \% \text { of the area })\end{array}$ & $\begin{array}{c}\text { Fluvic Neosol } \\
(7 \% \text { of the area })\end{array}$ \\
\hline Lateral soil hydraulic conductivity $\left(\mathrm{m} \mathrm{s}^{-1}\right)$ & 0.000019 & 0.000028 & 0.000033 \\
\hline $\begin{array}{c}\text { Exponential decrease rate of lateral soil hydraulic } \\
\text { conductivity }\end{array}$ & 0.005 & 0.300 & 0.010 \\
\hline $\begin{array}{c}\text { Vertical soil hydraulic conductivity in each soil } \\
\text { layer }\left(\mathrm{m} \mathrm{s}^{-1}\right)\end{array}$ & 0.0000190 & 0.0000280 & 0.0000330 \\
\cline { 2 - 4 } & 0.0000180 & 0.0000275 & 0.0000320 \\
\hline
\end{tabular}

Van Liew, Arnold and Garbrecht, (2003) suggest that $\mathrm{R}^{2}$ values higher than 0.50 are considered acceptable. The criteria proposed by Moriasi et al. (2007) was adopted for E, whose values from 0.50 upward qualify as acceptable and fit satisfactorily. Safeeq and Fares (2012) also reported that $\mathrm{E}$ values greater than 0.35 and less than 0.50 indicate average DHSVM performance; values between 0.50 and 0.70 indicate a good performance; and finally values greater than 0.70 indicate a very good performance (to daily values).

\section{Climate models: HadGEM2-ES Global and Eta/INPE Regional}

The physical configuration of the HadGEM2-ES model is derived from the HadGEM1 model, however, the HadGEM2-ES model is more complete and sophisticated, having an atmospheric component of 38 levels with a resolution of $1.274^{\circ}$ of latitude and $1.875^{\circ}$ of longitude. The oceanic component has 40 levels in the vertical and horizontal, the resolution varies from $1 / 3^{\circ}$ in the tropics to $1^{\circ}$ degree in the latitudes above $30^{\circ}$ (Collins et al., 2011).

The downscaling of the simulations carried out by the HadGEM2-ES model was produced by the Eta/INPE regional model, in the LW region. The version of the model (Eta) used in this study was developed for studies of climate changes in the South America (Pesquero et al., 2010; Chou et al., 2012) and received updates regarding the dynamic and physics of the model, which are described in Mesinger et al. (2012) and are incorporated in the version of the model for climate change studies (Chou et al., 2014a, b). Details about the Eta model/HadGEM2-ES and of climate change modeling in South America can be obtained in the studies developed by Chou et al. (2014a, b).

The study area was covered with six points corresponding to the horizontal resolution of $5 \mathrm{~km}$. The atmosphere is represented in the vertical until the pressure level of $25 \mathrm{hPa}$, with 38 levels.

\section{Future climate change scenario - RCP 8.5}

Until the end of the century, the radiative forcing in the RCPs 2.6, 4.5, 6.0, and 8.5, account for Approximately 490, 650,850 , and $1370 \mathrm{ppm}$ of concentration of $\mathrm{CO}_{2}$ equivalent, respectively (Van Vuuren et al., 2011). Thus, the RCP 8.5 scenario is the highest of all RCPs in terms of greenhouse gas emissions (IPCC, 2013). Emissions of greenhouse gases in the RCP 8.5 scenario continues to rise after the end of the twenty-first century as a result of the high intensity of energy sector and of land use, and also due to population increase associated with high demand for food (Riahi et al., 2011).

\section{RESULTS AND DISCUSSION}

\section{Projections of the Eta/HadGEM2-ES model}

Tables 2 (a) and (b) show the points 1, 2, 3, 4, 5 and 6 (P1, P2, P3, P4, P5 and P6) of the grid box of the Eta/ HadGEM2-ES simulations and of the Campos do Jordão (CJ), São Lourenço (SL) and Barbacena (B) stations, which are the nearest and with climatic conditions similar to those observed in the LW. The Barbacena and Campos do Jordão stations showed, respectively, observed data of monthly total precipitation and temperature closer to those simulated by the Eta/HadGEM2-ES for the 1961-1990 period.

The simulated and observed values showed that the rainy season presents maximum quarterly total precipitation and temperature values during the summer months of December, January and February (DJF). The dry season has quarterly minimum temperature and total precipitation values during the winter months of June, July and August (JJA). These results suggest that the quarterly average data of total precipitation and temperature projected by simulations Eta/HadGEM2-ES were able to capture the seasonal variation patterns during the 30-year period, from 1961 to 1990 (Table 2 (a) and (b)). 
Table 2: Quarterly average precipitation $(\mathrm{mm})$ in $(\mathrm{a})$ and quarterly average temperature $\left({ }^{\circ} \mathrm{C}\right)$ in $(\mathrm{b})$ of the simulated points (P1, P2, P3, P4, P5 and P6) and of the INMET stations [(Campos do Jordão (CJ), São Lourenço (SL) and Barbacena (B), in the 1961-1990 period (present climate)].

(a)

\begin{tabular}{cccccccc}
\hline Points and stations & Latitude & Longitude & Altitude $(\mathrm{m})$ & DJF & MAM & JA & SON \\
\hline P1 & $22^{\circ} 06^{\prime}$ & $44^{\circ} 30^{\prime}$ & 1587.10 & 146.3 & 62.2 & 48.1 & 112.0 \\
P2 & $22^{\circ} 06^{\prime}$ & $44^{\circ} 27^{\prime}$ & 1453.19 & 200.5 & 87.0 & 56.9 & 138.4 \\
P3 & $22^{\circ} 06^{\prime}$ & $44^{\circ} 24^{\prime}$ & 1442.14 & 188.4 & 84.5 & 56.7 & 134.4 \\
P4 & $22^{\circ} 09^{\prime}$ & $44^{\circ} 30^{\prime}$ & 1534.88 & 171.5 & 76.1 & 48.9 & 123.5 \\
P5 & $22^{\circ} 09^{\prime}$ & $44^{\circ} 27^{\prime}$ & 1443.11 & 191.2 & 85.5 & 52.6 & 133.5 \\
P6 & $22^{\circ} 09^{\prime}$ & $44^{\circ} 24^{\prime}$ & 1440.41 & 179.2 & 78.6 & 51.9 & 126.4 \\
CJ & $22^{\circ} 45^{\prime}$ & $44^{\circ} 36^{\prime}$ & 1642.00 & 290.6 & 123.9 & 50.7 & 152.3 \\
SL & $22^{\circ} 06^{\prime}$ & $45^{\circ} 01^{\prime}$ & 953.20 & 264.1 & 101.4 & 30.6 & 131.0 \\
B & $21^{\circ} 15^{\prime}$ & $43^{\circ} 46^{\prime}$ & 1126.00 & 225.1 & 78.9 & 21.9 & 140.9 \\
\hline Points and stations & Latitude & Longitude & Altitude (m) & DJF & MAM & JA & SON \\
\hline P1 & $22^{\circ} 06^{\prime}$ & $44^{\circ} 30^{\prime}$ & 1587.10 & 16.7 & 14.9 & 12.2 & 15.5 \\
P2 & $22^{\circ} 06^{\prime}$ & $44^{\circ} 27^{\prime}$ & 1453.19 & 17.5 & 15.6 & 12.9 & 16.2 \\
P3 & $22^{\circ} 06^{\prime}$ & $44^{\circ} 24^{\prime}$ & 1442.14 & 17.5 & 15.6 & 12.9 & 16.1 \\
P4 & $22^{\circ} 09^{\prime}$ & $44^{\circ} 30^{\prime}$ & 1534.88 & 17.1 & 15.2 & 12.6 & 15.9 \\
P5 & $22^{\circ} 09^{\prime}$ & $44^{\circ} 27^{\prime}$ & 1443.11 & 17.7 & 15.7 & 13.1 & 16.4 \\
P6 & $22^{\circ} 09^{\prime}$ & $44^{\circ} 24^{\prime}$ & 1440.41 & 17.6 & 15.6 & 13.0 & 16.2 \\
CJ & $22^{\circ} 45^{\prime}$ & $44^{\circ} 36^{\prime}$ & 1642.00 & 17.1 & 14.4 & 10.3 & 14.7 \\
SL & $22^{\circ} 06^{\prime}$ & $45^{\circ} 01^{\prime}$ & 953.20 & 22.1 & 19.1 & 15.1 & 20.1 \\
B & $21^{\circ} 15^{\prime}$ & $43^{\circ} 46^{\prime}$ & 1126.00 & 20.1 & 18.1 & 15.3 & 18.0 \\
\hline
\end{tabular}

December, January and February (DJF) - Summer; March, April and May (MAM) - Autumn; June, July and August (JJA) - Winter; and September, October and November (SON) - Spring.

Due to the complex and non-linear nature of the system there are many uncertainties involved in this study. Chou et al. (2014 a) also showed that the regions of complex topography, or in forests of difficult access, errors of climate simulations are associated with sparse distribution of observed data in Brazil (for comparisons). Still, evaluations of Eta simulations nested with HadGEM2-ES, BESM and
MIROC5 GCMs in the 1961-1990 period showed that the Eta/HadGEM2-ES performed well in the summer (DJF) and winter (JJA) seasons in southcentral Brazil.

Thus, Eta/HadGEM2-ES climate change simulations were considered suitable for a better understanding of the impacts, projected by the RCP 8.5 scenario, on the hydrologic response of LW. 
In Table 3, it is possible to note that the annual temperature and annual total precipitation averages designed by Eta/HadGEM2-ES in the RCP 8.5 scenario showed, respectively, an increase and decrease (in \%) over the twenty-first century, in points $\mathrm{P} 1, \mathrm{P} 2, \mathrm{P} 3, \mathrm{P} 4, \mathrm{P} 5$ and $\mathrm{P} 6$. The average annual results indicated that by the end of the twenty-first century the warming reached $7{ }^{\circ} \mathrm{C}(+46.7 \%)$ and the total precipitation was reduced by up to $479 \mathrm{~mm}$ $(-35.0 \%)$ compared to the present climate simulated by the Eta/HadGEM2- ES (1961-1990).

Variations of temperature and precipitation simulated for the 2011-2040, 2041-2070 and 2071-2099 periods (future scenario-RCP 8.5) are consistent with the trends shown in the study of Chou et al. (2014b), designed by Eta/HadGEM2-ES, for Southeast Brazil. These authors also suggest that the large reduction in precipitation in the region, particularly during December, January and February, may be associated with a decrease of both the occurrence frequency, as well as the intensity of the episodes, for the South Atlantic Convergence Zone (SACZ) in summer. The reduction of the occurrence frequency and activity of SACZ is also in line with the intensification of the subtropical high pressure that can block the passage of cold fronts in the region.

\section{Hydrologic simulation with DHSVM}

In Figures 2 (a) and (b) the daily and monthly streamflow simulated by DHSVM are reasonable according to the streamflow observed (2006-2010). These figures also expressed the results of the precision statistics (coefficient of determination- $\mathrm{R}^{2}$ and Nash-Sutcliffe efficiency-E) to evaluate the performance of DHSVM in the simulation of daily and monthly streamflow of the LW in the calibration and validation period. The statistical indices values were considered appropriate according to the classification of Van Liew, Arnold and Garbrecht, (2003), Moriasi et al. (2007) and Safeeq and Fares (2012).

Analysis in monthly time steps is used in most studies of climate changes impacts (Leung; Wigmosta, 1999; Viola et al., 2015); however, these studies simplify some numerical processes because the objective is to evaluate the impacts on hydrology in average terms. Thus, DHSVM was calibrated in the daily and monthly time step in this study because if the model is calibrated for daily time step with good results, the monthly time step is good enough as well.

The observed average annual streamflow in the LW was $0.25 \mathrm{~m}^{3} \mathrm{~s}^{-1}$ during the $2006-2010$ period (with an average annual precipitation observed of 2045 $\mathrm{mm})$. In this study the average annual streamflow and precipitation simulated by DHSVM were $0.16 \mathrm{~m}^{3} \mathrm{~s}^{-1}$ and $1326 \mathrm{~mm}$, respectively, during the 1961-1990 period (present climate). Therefore, although the average annual streamflow comparisons are in different periods, the underestimation of the simulated streamflow shows that there are errors and uncertainties in these simulations. Nevertheless, the observed and simulated values are in order of comparable magnitude. In Table 2 (a), the underestimation of the simulated precipitation during the summer (DJF) corroborates these statements.

Table 3: Changes in the annual temperature (Temp.) And total precipitation (Precip.) averages in \%, projected by the Eta / HadGEM2-ES model for the future scenario (RCP 8.5) in comparison to present climate (1961-1990).

\begin{tabular}{ccccccc}
\hline \multirow{2}{*}{ Points } & \multicolumn{5}{c}{ Future scenario (RCP 8.5) } \\
\cline { 2 - 6 } & \multicolumn{2}{c}{$2011-2040$} & \multicolumn{2}{c}{$2041-2070$} & \multicolumn{2}{c}{$2071-2099$} \\
\cline { 2 - 6 } & Temp. $\left({ }^{\circ} \mathrm{C}\right)$ & Precip. $(\mathrm{mm})$ & Temp. $\left({ }^{\circ} \mathrm{C}\right)$ & Precip. $(\mathrm{mm})$ & Temp. $\left({ }^{\circ} \mathrm{C}\right)$ & Precip. $(\mathrm{mm})$ \\
\hline \multirow{2}{*}{ P1 } & 18 & 865 & 19 & 939 & 21 & 813 \\
& $+20.0 \%$ & $-21.8 \%$ & $+26.7 \%$ & $-15.1 \%$ & $+40.0 \%$ & $-26.5 \%$ \\
P2 & 18 & 1060 & 20 & 1154 & 22 & 947 \\
& $+12.5 \%$ & $-26.8 \%$ & $+25.0 \%$ & $-20.3 \%$ & $+37.5 \%$ & $-34.6 \%$ \\
P3 & 18 & 1000 & 20 & 1087 & 22 & 891 \\
& $+12.5 \%$ & $-27.0 \%$ & $+25.0 \%$ & $-20.7 \%$ & $+37.5 \%$ & $-35.0 \%$ \\
P4 & 18 & 961 & 19 & 1046 & 22 & 882 \\
& $+20.0 \%$ & $-23.7 \%$ & $+26.7 \%$ & $-17.0 \%$ & $+46.7 \%$ & $-30.0 \%$ \\
P5 & 19 & 1030 & 20 & 1126 & 22 & 927 \\
& $+18.8 \%$ & $-25.8 \%$ & $+25.0 \%$ & $-18.9 \%$ & $+37.5 \%$ & $-33.2 \%$ \\
P6 & 18 & 964 & 20 & 1055 & 22 & 865 \\
& $+12.5 \%$ & $-26.3 \%$ & $+25.0 \%$ & $-19.3 \%$ & $+37.5 \%$ & $-33.9 \%$ \\
\hline
\end{tabular}




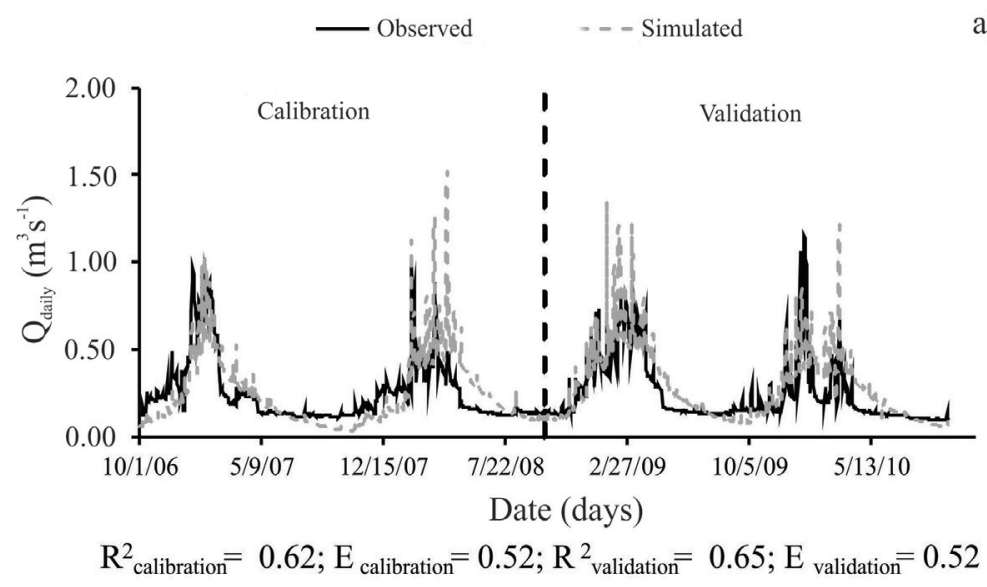

a)

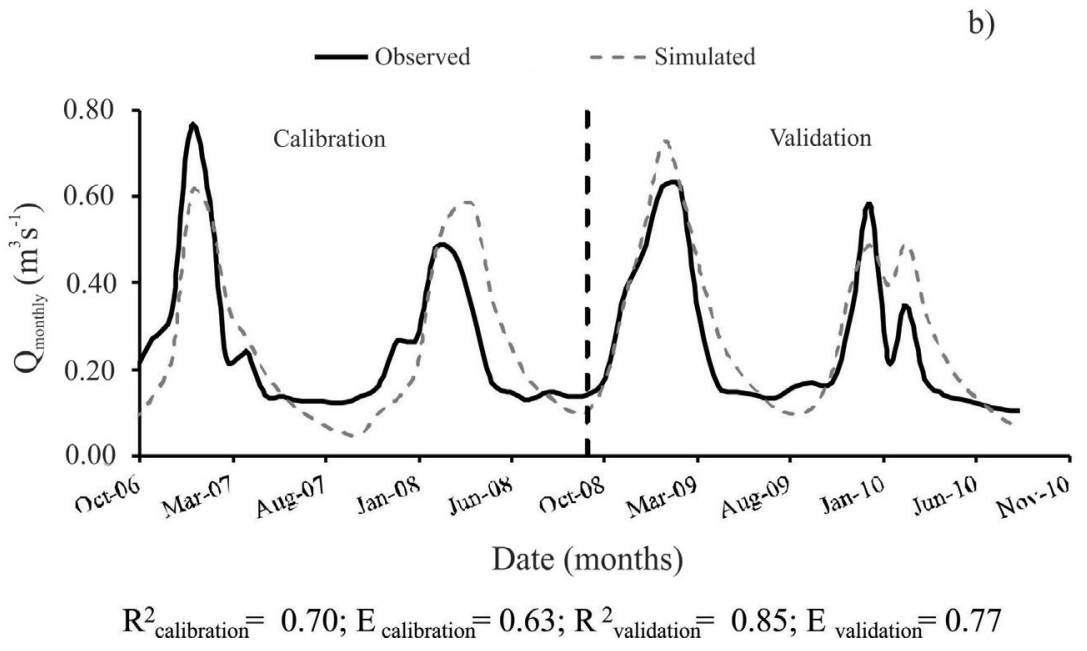

Figure 2: Daily (a) and monthly (b) observed and simulated streamflows during the calibration (October 1, 2006 to September 30, 2008) and validation (October 1, 2008 to September 30, 2010) periods of the DHSVM.

During the 1961-1990 period the average annual runoff was $753 \mathrm{~mm}$. For the RCP 8.5 future scenario, during the periods of 2011-2040, 2041-2070 and 20712099 , the average annual streamflows were respectively $0.06 \mathrm{~m}^{3} \mathrm{~s}^{-1}(282 \mathrm{~mm}), 0.07 \mathrm{~m}^{3} \mathrm{~s}^{-1}(330 \mathrm{~mm})$ and 0.05 $\mathrm{m}^{3} \mathrm{~s}^{-1}(235 \mathrm{~mm})$, i.e. a reduction of 63,56 and $69 \%$, respectively, compared to the 1961-1990 period. These reductions can produce very severe impacts on water availability in the region as a whole, and consequently in the generation of electricity from the Upper Grande River region.

Precipitation (interpolated precipitation data) and monthly average streamflows simulated by DHSVM in the LW for 1961-1990 (present climate), 2011-2040, 2041-2070 and 2071-2099 (future climates) are shown in Figures 3 (a) and (b) and Figures 4 (a) and (b). The seasonality of the average monthly streamflow for all periods remained consistent with the seasonality of the average monthly precipitation. In general, the maximum simulated streamflows were between October and March and the minimum between the months of April and September (Figures 3 (a) and (b) and Figures 4 (a) and (b)).

In the future scenario-RCP 8.5 (2011-2040, 20412070 and 2071-2099), only in the months of June and July did the precipitation show an increase between 8 and $63 \%$, respectively. For the other months of the year the monthly precipitation and streamflow showed the same reduction trend, on average, for the present climate (Figure 3 (b) and Figures 4 (a) and (b)). 
(a) Months (1961 to 1990)
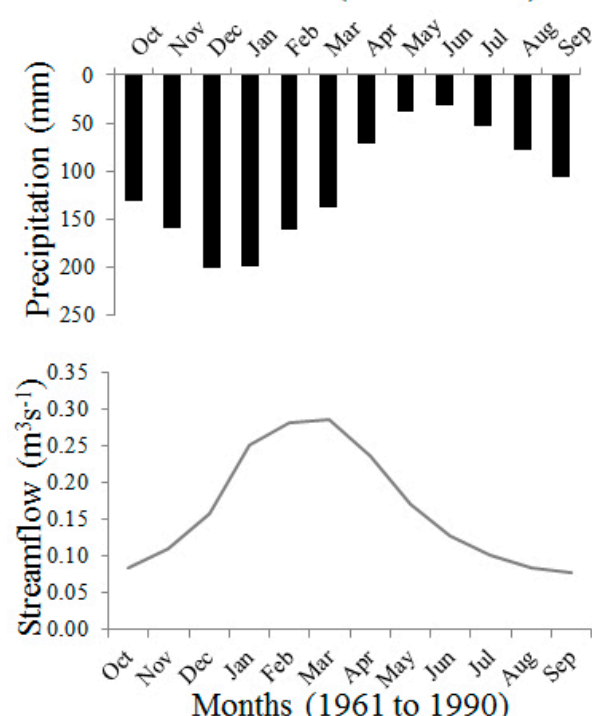

(b) Months (2011 to 2040)

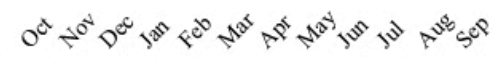
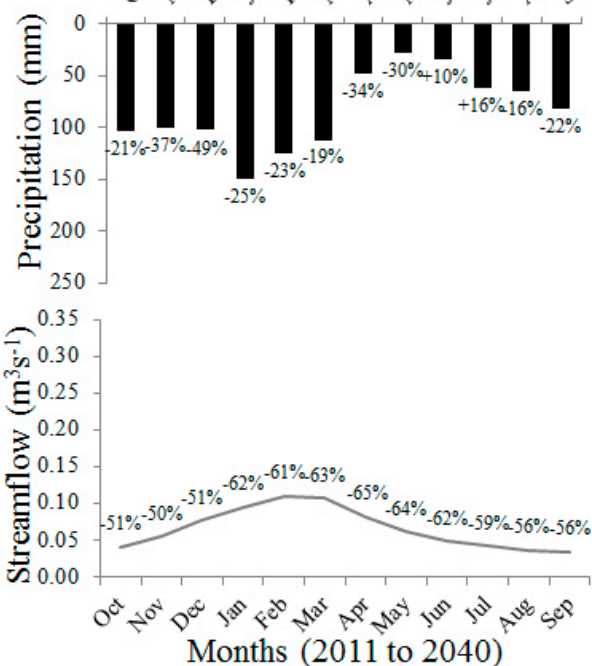

Months (2011 to 2040)

Figure 3: Monthly precipitation $\left(\mathrm{mm} \mathrm{month}^{-1}\right)$ and streamflow averages $\left(\mathrm{m}^{3} \mathrm{~s}^{-1}\right)$ simulated by DHSVM in the LW, for the present climate (1961-1990) in (a) and for the future climate projection during 2011-2040 simulated by the Eta/HadGEM2-ES model (RCP 8.5 scenario) in (b).

(a)

Months (2041 to 2070)

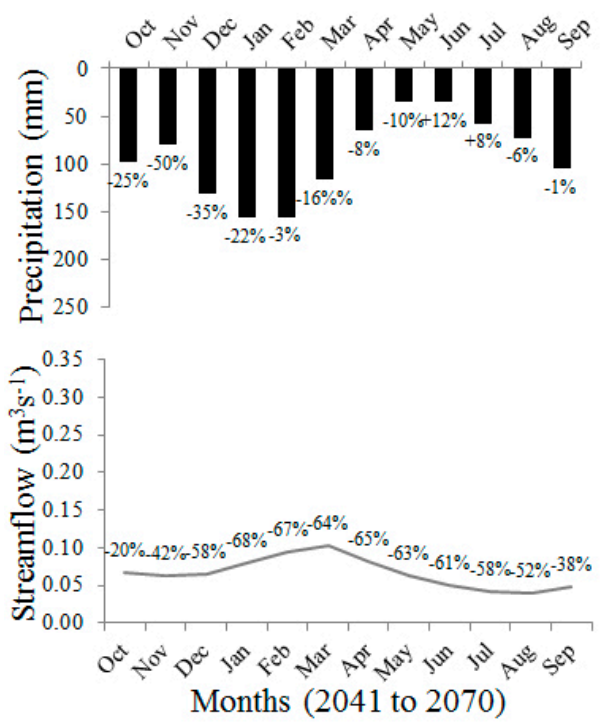

(b)

Months (2071 to 2099)
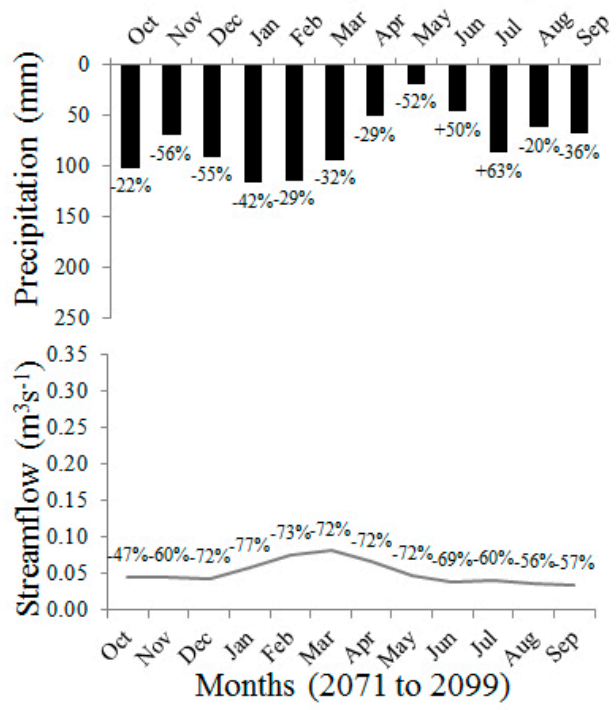

Figure 4: Monthly precipitation and streamflow averages simulated by DHSVM in LW for the future climate projection during 2041-2070 in (a) and for the future climate projections during 2071-2099 in (b) simulated by the Eta/HadGEM2-ES model (RCP 8.5 scenario).

In relation to the present climate, the future projections of average monthly simulated streamflows showed a decrease of up to $65 \%$ (April), $68 \%$ (January) and $77 \%$ (January) during the periods 2011-2040, 2041-2070 and 2071-2099 (future scenario-RCP 8.5), respectively. Therefore, the greatest impacts on the LW hydrology could occur at the end of the XXI century (2071- 2099) (Figure 3 (b) and Figures 4 (a) and (b)). 
The results also showed that the LW hydrology is strongly influenced by the wet season. Thus, the positive effects regarding the increase in precipitation in the dry season were less pronounced than in the rainy season (Figure 3 (b) and Figures 4 (a) and (b)).

Safeeq and Fares (2012), using DHSVM, studied the climate sensitivity of the hydrological components in a watershed in Hawaii, United States, whose drainage area is $13.84 \mathrm{~km}^{2}$. The authors simulated the hydrologic response for 43 years, taking into account future scenarios of the AR4. For the climate scenario A1FI (high emission of greenhouse gases) they verified that the increase of $6.4{ }^{\circ} \mathrm{C}$ in the air temperature reduced $2.6 \%$ of the average annual streamflow, and a $20 \%$ decrease in the precipitation resulted in a decline of up to $50 \%$ in the annual streamflow of the watershed.

Other authors, like Dickerson-Lange and Mitchell (2014), also combined climate change simulations of three GCMs of the AR4 (GISS, Echam and IPSL) with the DHSVM to assess the impacts on the Nooksack River watershed, in the State of Washington, United States. This watershed has an area of $2000 \mathrm{~km}^{2}$. It was found that from 2000 to 2075 the future climate projections indicated an increase of the average monthly temperature in summer of up to $5.2^{\circ} \mathrm{C}$ and variation in the precipitation changes in different seasons. Simulated future streamflow indicated an increase in the winter up to $88 \%$ and decrease in summer up to $50 \%$.

Viola et al. (2015) also evaluated the possible hydrological changes in the watershed of the Rio Grande, in the state of Minas Gerais, Brazil. This study covered a larger area (watershed with drainage area of 2095, 2080, 7325 and $4178 \mathrm{~km}^{2}$ ). In the hydrologic simulations the Lavras Simulation of Hydrology (LASH) model was used associated with the simulations of the Eta/HadCM3 to the A1B emission scenario of the AR4 in the twentyfirst century. Although the study cited was done in the same study area as this present work, the results of both surveys indicated different hydrologic trends. Between 2011 and 2040, the results of Viola et al. (2015) showed that a reduction may occur in the annual streamflow. However after 2041 the projections indicated that with the increasing precipitation over the XXI century there may occur an increase in the mean annual streamflow (Marengo et al., 2012).

It is valid to emphasize that the future climate scenario A1B (AR4) can be considered as an intermediate scenario between the A2 scenario (high greenhouse gas emissions) and B2 scenario (low greenhouse gas emissions). In this present study the future climate scenario-RCP 8.5 (AR5) was used, which has radiative forcing corresponding, approximately, to the A2 scenario (AR4). Therefore the differences in the hydrologic trend behavior of this study (Eta/HadGEM2-ES, RCP 8.5) compared to that verified by Viola et al. (2015) (Eta/ HadCM3, A1B) highlight the necessity of developing more regional studies using different GCMs for climate projections of different future scenarios.

Finally, in the present study the reduction in the monthly and annual average streamflows is due to the increase and decrease in the monthly average temperature and precipitation in the region of this study. These changes in the streamflow (on a micro-scale) that depend on future temperature and precipitation have a high degree of uncertainty. However, despite the uncertainties of the simulated projections, the results presented provide an indication of how the hydrological conditions of the LW may change in a possible future scenario of high greenhouse gas emissions. Moreover, it is also important to emphasize that this is a pioneering study of one of the most important headwater regions of the Brazil (Mantiqueira Range).

In general, the results indicate drastic changes in the hydrologic response of the LW in all months of the year and in the annual average. Therefore, it should be noted here that the mitigation of greenhouse gases is an important target to be considered for the future of water resources in this region.

\section{CONCLUSIONS}

In the future climate-RCP 8.5 scenario, changes projected over the twenty-first century resulted in annual and monthly average streamflow reduction of up to 69 and $77 \%$, respectively. The projected period of 20712099 was considered the most critical when compared to present climate. Thus, the decrease in accumulated precipitation and the increase in air temperature can compromise power generation and water availability in the Mantiqueira Range region. As the occurrence of a water crisis in the region studied is increasingly plausible, strategic mitigation and adaptation should be developed. This research did not explore the uncertainties inherent to the emission scenarios; on the contrary, we only used the highest emission scenario to indicate the possible more drastic changes. The HadGEM2-ES model is often pointed to as one of the global models most sensitive to $\mathrm{CO}_{2}$ concentration increases, in which, combined with the RCP 8.5 scenario, the most negative impacts were estimated. In the future it will be possible to evaluate the uncertainties of the hydrological forecasting in the LW using other GCMs for climate projections. Thus, there 
will the possibility of obtaining more members of a set of projections to estimate uncertainty of the predicted values. In subsequent studies, for better vulnerability analysis regarding projected impacts, the development of hydrological simulations involving other future climate scenarios also can be suggested.

\section{ACKNOWLEDGEMENTS}

We would like to thank the CAPES Foundation for the visiting scholarship (doctoral research) at Purdue University (Process 99999.014035/ 2013-08), and FAPEMIG for the doctorate scholarship provided to the first author. Acknowledgments to MCTI and PNUD by project BRA/10/G32 for support in the generation of regionalized scenarios. Acknowledgments to the $\mathrm{CNPq}$ for partial funding through 308035/2013-5, 400792/2012-5 and 457874/2014-7 projects.

\section{REFERENCES}

ALVARENGA, L. A. et al. Assessment of land cover change on the hydrology of a Brazilian headwater watershed using the Distributed Hydrology-Soil-Vegetation Model. CATENA. 143:7-17, 2016.

ÁVILA, L. F. et al. Partição da precipitação pluvial em uma microbacia hidrográfica ocupada por Mata Atlântica na Serra da Mantiqueira, MG. Ciência Florestal. 24(3): 583-595, 2014.

$\mathrm{CHOU}, \mathrm{S}$. C. et al. Evaluation of the Eta simulations Nested in Three Global Climate Models. American Journal of Climate Change. 3(5):438-454, 2014a.

CHOU, S. C. et al. Assessment of climate change over South America under RCP 4.5 and 8.5 downscaling scenarios. American Journal of Climate Change. 3(5):512-525, $2014 \mathrm{~b}$.

CHOU, S. C. et al. Downscaling of South America present climate driven by 4-member HadCM3 runs. Climate Dynamics. 38(3-4):635-653, 2012.

COELHO, C. A. et al. The 2014 southeast Brazil austral summer drought: Regional scale mechanisms and teleconnections. Climate Dynamics. 46(11): 3737-3752, 2015.

COLLINS, W. J. et al. Development and evaluation of an Earth-system model-HadGEM2. Geoscientific Model Development. 4(4):1051-1075, 2011.

CUARTAS, L. A. et al. Distributed hydrological modeling of a micro-scale rainforest watershed in Amazonia: Model evaluation and advances in calibration using the new HAND terrain model. Journal of Hydrology. 462-463:15-27, 2012.
DICKERSON-LANGE, S. E.; MITCHELL, R. Modeling the effects of climate change projections on streamflow in the Nooksack River basin, Northwest Washington. Hydrological Processes. 28(20):5236-5250, 2014.

FLATO, G. et al. The Physical Science Basis. In: STOCKER, T. F. et al. (ed). Contribution of working group I to the fifth assessment report of the intergovernmental panel on climate change. United Kingdom and New York: Cambridge University Press, Cambridge, 2013. 1535p.

INTERGOVERNMENTAL PANEL ON CLIMATE CHANGE - IPCC. Summary for policymakers. In: Climate change 2013. The physical science basis. Cambridge: Cambridge University Press, 2013. $571 \mathrm{p}$.

JUNQUEIRA JUNIOR, J. A. et al. Continuidade espacial de atributos físico-hídricos do solo em sub-bacia hidrográfica de cabeceira. Ciência e Agrotecnologia. 32(3):914-922, 2008.

KRUK, N. S. et al. Análise de sensibilidade do modelo hidrológico distribuído DHSVM aos parâmetros de vegetação. Revista Brasileira de Recursos Hídricos. 14(1):75-84, 2009.

LEUNG, L. R.; WIGMOSTA, M. S. Potential climate change impacts on mountain watersheds in the Pacific Northwest. Journal of the American Water Resources Association. 35(6):1463-1471, 1999.

MARENGO, J. A. et al. Development of regional future climate change scenarios in South America using the Eta CPTEC/ HadCM3 climate change projections: Climatology and regional analyses for the Amazon, São Francisco and the Paraná River basins. Climate Dynamics. 38(9-10):18291848, 2012.

MELLO, C. R. de et al. Sea surface temperature (SST) and rainfall erosivity in the Upper Grande River Basin, Southeast Brazil. Ciência e Agrotecnologia. 36(1):53-59, 2012.

MELLO, C. R de et al. Agricultural watershed modeling: A review for hydrology and soil erosion processes. Ciência e Agrotecnologia. 40(1):7-25, 2016.

MENEZES, M. D. de et al. Solum depth spatial prediction comparing conventional with knowledge-based digital soil mapping approaches. Scientia Agricola. 71(4):316323, 2014.

MESINGER, F. et al. An upgraded version of the Eta model. Meteorology and Atmospheric Physics. 116(3):63-79, 2012. 
MORIASI, D. N. et al. Model evaluation guidelines for systematic quantification of accuracy in watershed simulations. Transactions of the ASABE. 50(3):885-900, 2007.

PESQUERO, J. F. et al. Climate downscaling over South America for 1961-1970 using the Eta model. Theoretical and applied climatology. 99(1-2):75-93, 2010.

PINTO, L. C. et al. Micromorphology and pedogenesis of mountainous inceptisols in the Mantiqueira range (MG). Ciência e Agrotecnologia. 39(5):455-462, 2015.

RAMOS, A. M.; SANTOS, L. A. R.; FORTES, L. T. G. Normais climatológicas do Brasil 1961-1990. DF: INMET, 2009. $465 p$.

RIAHI, K. et al. RCP 8.5-A scenario of comparatively high greenhouse gas emissions. Climatic Change. 109(1-2):3357, 2011.
SAFEEQ, M.; FARES, A. Hydrologic response of a Hawaiian watershed to future climate change scenarios. Hydrological processes. 26(18):2745-2764, 2012.

VAN LIEW, M. W.; ARNOLD, J. G.; GARBRECHT, J. D. Hydrologic simulation on agricultural watersheds: Choosing between two models. Transactions of the ASAE. 46(6):1539-1551, 2003.

VAN VUUREN, D. P. et al. The representative concentration pathways: An overview. Climatic Change. 109(1):5-31, 2011.

VIOLA, M. R. et al. Assessing climate change impacts on Upper Grande River Basin hydrology, Southeast Brazil. International Journal of Climatology. 35(6):1054-1068, 2015.

WIGMOSTA, M. S.; VAIL, L. W.; LETTENMAIER, D. P. A distributed hydrology-vegetation model for complex terrain. Water Resources Research. 30(6):1665-1679, 1994. 